\title{
STRUCTURE-ACTIVITY RELATIONSHIP OF OCTREOTIDE ANALOGUES \\ LABELED WITH RHENIUM AND TECHNETIUM-99m \\ Shorouk Dannoon
}

\begin{abstract}
The goal of this research is to cyclize octreotide analogues with ${ }^{99 \mathrm{~m}} \mathrm{Tc}$ and ${ }^{186 / 188} \mathrm{Re}$ radiometals to be used as diagnostic and therapeutic agents for neuroendocrine tumors, respectively. Several series of octreotide analogues that differ in their sequences, and/or coordination systems $\left(S_{2} N_{2}\right.$ and $\left.S_{3} N\right)$ were developed. Their in vitro receptor binding affinity toward somatostatin receptors was measured via $\mathrm{IC}_{50}$ studies.
\end{abstract}

In vitro stability studies were carried out under physiological conditions on ${ }^{99 m}$ Tc-cyclized analogues in phosphate buffered saline, mouse serum, and under high cysteine concentration. The only analogue that expressed high receptor binding affinity was not stable at the tracer level; however, the other analogues were stable at the tracer level but at the expense of their receptor affinity.

The effect of metal-cyclization on Tyr ${ }^{3}$-octreotate's receptor binding site was determined via three-dimensional molecular structure calculation, using twodimensional NMR experiments as experimental constraints. From the obtained structures, it was concluded that the metal-cyclized Tyr ${ }^{3}$-octreotate's receptor binding site configuration was, to some extent, similar to that of the usually disulfide-cyclized counterpart. 